\title{
The Development of the Root System of the Genus Astragals Species in Southern Kazakhstan
}

\author{
Alzhanov EA*, Esembekova GB and Miltikbaeva GC \\ South State University, SHimkent, South Kazakhstan Region, Kazakhstan
}

\begin{abstract}
Root - the most important vegetative plant organ with a complex morphology and structure multiple functions in communication with the underground plant components of the environment. The development of the root system of 3 species of Astragalus in ontogeny, studied in the south of Kazakhstan. The root of Astragalus turczaninovii seedlings in the sowing (April) clearly expressed rod length of $14-17 \mathrm{~mm}$. In juvenile plant root length of $16-21 \mathrm{~mm}$, lateral roots $5 \mathrm{~mm}$. On hypocotyl marked transverse folds and wrinkles, which is a sign of the root retraction.
\end{abstract}

Keywords: Root system; Genus astragals species; Vegetative plant organ

\section{Introduction}

In the immature state the length of taproot $13-14 \mathrm{~cm}$, developed short lateral roots $(5-7 \mathrm{~cm})$ of the first order. By the end of the first year the plant is growing in the immature state, the main root is $25-30 \mathrm{~cm}$ in the horizon - A (sandy loam), at a depth of 6-7 cm from the soil surface developed lateral roots, length 5-6 cm, the root of A. turczaninovii grows slowly in the state, but in the adult vegetative ahead of other species. The root of the young plant generative core, length $75-80 \mathrm{~cm}$ penetration in the sun horizon (loamy). At a depth of 5-7 cm depart first lateral roots. The number of lateral roots is less than 8 . They extend to $25-37 \mathrm{~cm}$ in horizon B2 (compacted sandy loam) at a depth of 30-40 $\mathrm{cm} 3$ species of Astragalus [1].

Thus, the young generative state of the main root is located in the loamy soil horizon and reaches a depth of $80.0 \mathrm{~cm}$, the side in the sandy loam horizon. The main root of the middle-plant reaches a length of $90.0 \mathrm{~cm}$, penetrating the plaster sun horizon. The upper part of the taproot thicker to $0.8 \mathrm{~cm}$ at a depth of $5-30 \mathrm{~cm}$. In loamy B2 horizon of the main root of the roots extend to 142 order. The old-age plant main root length of $130.0 \mathrm{~cm}$, with a diameter of $1.1 \mathrm{~cm}$ root collar, girth area 1.1-1.3 $\mathrm{m}^{2}$. It reaches to the horizon CI (gypsum layer), where the middle part of it dies. Two lateral roots - of the order of (10-11) arranged horizontally within the horizon $\mathrm{B} 2$ and $\mathrm{BC}[2]$.

Astragalus root system refers to the rod-like fibrous. The conditions in the south of Kazakhstan A. turczaninovii in generative period of ontogenesis, universal type of root system, the root system is concentrated in the sandy loam and loamy B2, the CK horizons, but the main root is able to penetrate the gypsum horizon CI. The main root in step G3 starts to die off in the seventh year of vegetation [3].

The root of Astragalus alopecias seedlings in the sowing (April) clearly expressed core, $18-20 \mathrm{~mm}$ in length. In juvenile plant taproot length of $60-72 \mathrm{~mm}$. At a depth of $6 \mathrm{~cm}$ formed lateral roots of the first order of $5 \mathrm{~mm}$ long. In the immature period, the length of the main taproot of 8-10 cm, at a depth of 4-5 cm, 3-4 laid horizontal lateral roots that penetrate into the horizon A (sandy loam) at a depth of 4-5 $\mathrm{cm}$ in adult vegetative state taproot alopecias. Deepened to 19.0-21.0 $\mathrm{cm}$ in horizon B2 (compacted sandy loam), the length of lateral roots $10-15.0 \mathrm{~cm} \mathrm{[4].}$

Young generative plants develop a taproot, stay vertically to a depth of $80-85 \mathrm{~cm}$, in the horizon of the sun. Sinking apex persists. At a depth of $20 \mathrm{~cm}$ in horizon BI first lateral roots depart. The main area of proliferation of lateral roots is at a depth of $20-60 \mathrm{~cm}$ from the soil surface in sandy loam horizon B2. Lateral roots are few and 4 . They extend in the B2 horizon (compacted sandy loam) and the sun (light loam), mainly horizontal, deep into the soil horizon gipsirovannuyu CK (plaster coat) [5].

At the middle-upper part of the generative plant taproot thickened up to $6 \mathrm{~cm}$ penetration depth of the main root 110.0-120.0 see in the horizon the CK. At a depth of $40.0 \mathrm{~cm}$ in sandy loam horizon - the sun from the main roots extend to 6-7 2 orders and sight roots, length $30-50.0 \mathrm{~cm}$ in old-age plants apical and middle part of the main root is dying at a depth of $80,0 \mathrm{~cm}$, but the total length of the roots to a depth of $170 \mathrm{~cm}$ with 6-8 II of the order of roots penetrating the horizon $\mathrm{C} 1$ (detrital dense layer), with the girth area of 1.4-1.6 $\mathrm{m}^{2}[6]$.

Phonological observations allow us to establish inter-conditionality of the rhythm of development of plants and the environment. Phenophases morphologically expressed in the appearance of plants on certain organs: kidneys, leaves, buds, flowers, fruits, closely linked to the changes within the plant, depending not only on their genetic characteristics, but also on external conditions.

\section{References}

1. Bizhanova GK (2003) Modern state and mapping of the vegetation. Botanical science in the service of sustainable development of the Central Asian countries: Tez. Rep-Almaty pp: 122-124.

2. Ibragimov T, Abdraimov CA, Seitkarimov A (2003) By studying the flora of the south-eastern Kyzylkum. Botanical science in the service of sustainable development in Central Asia. Tez. Rep-Almaty pp: 78-81.

3. Bekhzod A, Tashkhonim R, Nodira R., Rano A, Mirqosim S et al. (2016) Present state of pasture types of the central KyzylKum. American Journal of Plant Sciences 7: 677-683.

4. Saidov DK (1977) Ecological and biological basis for the creation of artificial desert pastures and hayfields on fergana valley-tashkent. Fan p: 158.

${ }^{*}$ Corresponding author: Alzhanov EA, South State University, SHimkent, South Kazakhstan Region, Kazakhstan, Tel: 77713149422; E-mail: ericaljanov@mail.ru

Received December 16, 2016; Accepted December 24, 2016; Published December 30, 2016

Citation: Alzhanov EA, Esembekova GB, Miltikbaeva GC (2016) The Development of the Root System of the Genus Astragals Species in Southern Kazakhstan. Int J Swarm Intel Evol Comput 5: 144. doi: 10.4172/2090-4908.1000144

Copyright: (c) 2016 Alzhanov EA, et al. This is an open-access article distributed under the terms of the Creative Commons Attribution License, which permits unrestricted use, distribution, and reproduction in any medium, provided the original author and source are credited. 
Citation: Alzhanov EA, Esembekova GB, Miltikbaeva GC (2016) The Development of the Root System of the Genus Astragals Species in Southern Kazakhstan. Int J Swarm Intel Evol Comput 5: 144. doi: 10.4172/2090-4908.1000144

Page 2 of 2

5. Saidov DK (1980) Instructions for the creation of artificial meadows and Senoko owls on degraded lands of Andijan, Gulbahor lands of Fergan Valley. Information Report Tashkent 241: 19.
6. Khasanov O.Kh (2003) The genus of Medicago L. in the flora of Kazakhstan Botanical science for sustainable development in Central Asia: Tez. Report. Almaty pp: 105-106 